\title{
Effect of Anasakti and Level of Post on Job Satisfaction of Employees
}

\author{
Pushpendra Rao Upadhyay*, Dr. A.C. Vashishtha**
}

\section{ABSTRACT:}

The present study aims to study the effect of anasakti and level of post on job satisfaction of employees. The study was guided by the hypothesis that there will be no significant effect of anasakti and level of post on job satisfaction of employees. For this purpose sample was consisted of 120 employees were selected through quota random sampling. The data were collected through standardized tools from each subject individually. A 2 X3 factorial design was employed to find out the effect of anasakti and level of post on job satisfaction. The obtained raw data were analyzed by Mean, SD, Newman-Kules and Analysis of variance (ANOVA).The results indicated that the anasakti and level of post was significantly affect the job satisfaction of employees.

Keywords: Anasakti, level of post, Job satisfaction, Employees.

\section{INTRODUCTION}

Asakti and Anasaktiboth are the Sanskrit term recognized as Bi-dimensional personality types in Indian psychology like the trait attachment and non-attachment in western psychology. (Bhusan, 1994) define Asakti (attachment) and Anasakti (non-attachment) as a Bi-polar of the same personality dimension.Banth and Talwar (2006, 2011) suggested that anasakti Sanskrit term for traits like non-attachment, equipoise, selfless duty orientation and efforts in the absence of concern for the outcome, can be regarded as a Hindu-ideal cluster of personality traits. Everyone possesses a certain degree of attachment and non-attachment but no one hundred percent "attached" or hundred percent "detached". Like any Bi-polar personality characteristics individual differ in its magnitude. Some are high in attachment (low in detachment) while others may be high in detachment (low in attachment). In most others cases we find a mixture of the two manifested in ambivalent behaviour (Bhushan, 1994). Taking Asakti (attachment) and (Anasakti) detachment as the two extreme points on a continuum, we can define the construct operationally and identify who is an attached or detached person. Attachment-detachment manifests in a variety of thinking, feeling and action patterns. This would be based on the description given in the Bhagavad Gita.

*Research Scholar, Dept. of Psychology Meerut College, Meerut.

**Professor, Dept. of Psychology, Meerut College, Meerut.

(C) 2014 A Vashishtha, P Upadhyay; licensee IJIP. This is an Open Access Research distributed under the terms of the Creative Commons Attribution License (http://creativecommons.org/licenses/by/2.0), which permits unrestricted use, distribution, and reproduction in any Medium, provided the original work is properly cited. 
In generic sense Asakti means attraction towards any individual or object to gain its fruits or result and Anasakti is opposite to the Asakti. Asakti (Attachment) arouses the idea of possession, the sense of ownership. It gives rise to dependence on attachment to objects for deriving some excitement and pleasure. Naturally a person high in attachment becomes a victim of his expectations and their fulfilment, circumstances and events. He cannot escape the torments of victory and defeat. Like a pendulum he swings from elation to sorrow. Anasakti (nonattachment), on the other hand, develops internal freedom. "It frees you from the fetters which bind you to the ordinary plane of awareness. A man who is anasakt may enjoy the pleasures of life, acquire wealth and status, raise a family that he loves, and control a vast business or even an empire. However, he is never dependent on them. He enjoys everything but as the master and not the slave. He develops an inner freedom or independence and remains unaffected by success and failure. Detachment, therefore, is an ability to remain unaffected in the face of the trials and tribulations of life (Saraswati, 1984). Anasakti does not mean a negation of love. On the other hand, it is actually an extension of the limited relationship of love without an expectation. A person who is really detached loves all without discrimination, without considering who is his near relation, friend or enemy. He loves all without involvement and expectation. The love of a detached (Anasakt) person creates a supremacy of benevolence in his character. In Indian psychology, the term moha which literally means 'narrowing the area of consciousness' is used as a synonym for asakti. So, the higher one is in attachment, the narrower the area of intimacies, relationships and so-called love. On the other hand, the higher one is in detachment, the greater the area of oneness and love.

Pande and Naidu (1992) explained that anasakti involves acceptance of life circumstances without attachment to them, along with committed action (anasakt action), without expectations of rewards or results. The authors stated that anasakt action does not mean refraining from physical activity, but involves intense and impartial action while not being focused on evaluation or desire for success or gain. The authors further explained that anasakt action thus involves an individual becoming one with his or her actions, minimizing energy expenditure, which allows for more energy to focus on producing increased quality and a productivity among most daily tasks.

Anasakti (Nonattachment) also has similarities to the Buddhist concept of equanimity, a balanced mind state where mental reactions are observed while the mind remains peaceful. Equanimity, as explained by Hanson (2009), involves observing the content passing through the mind, as it "breaks the chain of suffering by separating the feeling tones of experience from the machinery of craving, neutralizing your reactions to those feeling tones" (p. 109). The author indicated that this de-conditioning and non-grasping approach to life can allow the dormant potential of positive emotions and action such as compassion to arise. Eventually, nonattachment and equanimity lead to actions being guided by values and not by habitual craving, avoidance or other reactions to positive or negative internal mental stimuli (Hanson, 2009).

As a construct, job satisfaction is extremely complex with no single conceptual model completely and accurately describing the construct (Hagedorn, 2000). Job satisfaction has been defined as "a pleasurable or positive emotional state resulting from the appraisal of one's job or 
job experiences" (Locke, 1976, p. 1300). Vroom (1964) defined job satisfaction as the attitude an individual carries about work roles and the corresponding relationship to worker motivation. Variables that influence job satisfaction include promotional opportunities, positions that provide high pay, considerate and participative supervision, opportunities to interact with peers, a variety of duties and a high degree of control over work methods and pace.

Job satisfaction refers to a dedicated evaluation of the job as a whole, but also refers to components such as financial rewards, resources to get the job completed, interest, challenge, use of valued skills, variety, occupational prestige, autonomy, relations to co-workers and supervisors, involvement in decision making, and comfort factors such as hours, physical surroundings and travel time. The essence of job satisfaction is the fit of congruence of the worker and the job (Mortimer, 1979). Job satisfaction is concerned with the attitudes people have about work rather than efforts to fill a need, or the past tense involving outcomes already experienced. Comparatively, motivation suggests the present tense where individuals strive toward an outcome. While different in context, satisfaction and motivation are related and both are used to evaluation of employees. Motivation has been defined as a crucial issue that influences activities of individuals in organizations, which results in job satisfaction (Padde, 1993). Numerous studies have been completed over the years in an attempt to classify, determine and/or predict job satisfaction (Locke, 1976). The studies can be grouped into two approaches: content and process (Buford and Bedeian, 1988). Herzberg (1959), Vroom (1964), Maslow (1970), Locke (1976) and McGinnis (1985) have studied what motivates individuals to behave in a certain way and strive toward a particular behavior. Herzberg's (1959) study distinguished two factors that influenced job satisfaction. Intrinsic factors, or motivators, (i.e., interest in the job, achievement, work and recognition) lead to job satisfaction while extrinsic factors, or hygienes, (i.e., policy and administration, an individual's relationships with peers and supervisors, working conditions, job security and pay) lead to job dissatisfaction. The theory was based on satisfaction whereby employees are motivated from within and are not self-motivated (Herzberg, Mausner and Snyderman, 1959).

A national study of male workers found that job satisfaction was most likely related to egorelated factors such as interest, variety, responsibility and competence (Gurin, Veroff\& Feld, 1960). Kohn and Schooler's (1973) study of American workers suggested job satisfaction is closely tied to closeness of supervision, routinization of work and substantive complexity. The significance of autonomy and job scope (Shepard, 1973; Stone, 1976) and opportunities to use one's ideas and skills, learn new things, and set one's own pace of work are additional items leading to job satisfaction (Tannenbaum, Kavic, Rosner, Vianello, \&Wieser, 1974). Other studies have focused on degree of formalization, centralization and complexity, decision-making and styles of supervisory personnel in managing conflict (Newman, 1975; Seashore and Taber, 1975; Locke, 1976). Individual differences in worker characteristics have been found to not be ofcrucial importance in generating job satisfaction and dissatisfaction; therefore, the same work features generally contribute to the satisfaction of all workers in the same way with the level of importance the basic variance (Voydanoff, 1978). With work characteristics not of considerable 
importance, job satisfaction changes have been found to be related to workers' subjective reactions to their jobs and noted improvements in efforts to enrich and/or enlarge jobs, increased economic benefits and security or enhanced working conditions and relationships (Mortimer, 1979). O'Toole (1973) found workers responding to self-fulfillment in their work through meaningful, enriching, growth-inducing work.

Motivation toward job satisfaction involves the attraction to a job for a variety of reasons before the job is taken. After assuming the position, individuals must be encouraged to put forth enough interest and energy to result in an acceptable effort. Finally, human resources must be developed and maintained to bring about success to the organization (Vroom, 1983). Studies by McGinnis (1985) supported that motivation and job satisfaction by subordinates in relation to supervisors can be enhanced with these suggestions: 1) expect the best from people you lead; 2) establish high, yet realistic, standards for excellence; 3) create an environment where failure is not fatal; 4) recognize and applaud achievement; 5) appeal sparingly to the competitive urge; 6) place a premium on collaboration; and 7) take steps to keep your own motivation high.

The Hierarchy of Needs developed by Maslow (1970) provided a basic foundation for understanding individuals' needs and desires. The theory was established with the premise that certain needs must be met before proceeding to higher levels of desires. Basic needs such as food, clothing and shelter must be met for survival. More complex desires included safety, belonging and love, self-esteem and status and self-actualization. Gruneberg (1979) used Maslow's theory to provide some evidence of job satisfaction of workers. Individuals employed in lower level-type occupations were more likely to be motivated by pay and security. After basic needs were met, higher level-type occupations were more interested in fulfilling higher order needs.

McClelland (1973) developed the Achievement Theory that suggested achievers have three basic qualities: 1) they like situations in which they take personal responsibility for finding solutions to problems, 2) they have a tendency to set moderate achievement goals and to take calculated risks and 3) they want concrete feedback about how well they are doing. Achievement varies per the individual. Therefore, managers can structure work situations to fully use the talents of high need for achievement individuals.

The Goal Setting Theory operates under the premise that a person's goals and intentions regulate a person's behavior. Research studies by Locke (1976) suggested that setting specific goals results in higher productivity. Managers can further enhance employee productivity by providing feedback on goal attainment.

Each of the motivational theories provide suggestions for measuring job satisfaction, but conflict in any of the theories arises when some factors may serve as job satisfaction factors for some and not others. The local administrator has an important role in creating, monitoring and maintaining the expectancies and reward structures that lead to job satisfaction. Administrators need to provide clear goals for subordinates while also being aware and making adequate use of 
organizational goals, philosophies and rewards. Administrators must use a contingency approach that is flexible, multifaceted and based on astute diagnosis of the situation (Kast\&Rosenzweig, 1985).

\section{METHODOLOGY}

\section{Objectives of study:}

1. To study the effect of anasakti on job Satisfaction of employees.

2. To study the effect of level of post on job Satisfaction of employees

3. To study the interaction effect between anasakti and level of post on job Satisfaction of employees.

\section{Hypotheses:}

Following hypotheses were formulated for empirical verification in connection with the fulfillment of the objectives of the present study.

1. There will be no significant effect of ansakti on job Satisfaction of employees.

2. There will be no significant effect of level of post on job Satisfaction of employees.

3. There will be no significant interaction effect of anasakti and level of post on job Satisfaction of employees.

\section{Design of the study:}

A $2 \times 3$ groups design was employed in the present research. The first independent variable of the study was ansakti which was consisted of two groups, i.e. high anasakti and low anasakti. The second independent variable of the study was the level of post that was varied at three levels, i.e. high, medium and low level of post. The dependent variable of the study was job satisfaction.

\section{Sample:}

In this research sample was consisted of 120male employees of International Automobile Organizations located at Faridabad, Haryana. Subjects with the average age of 26 years were selected through quota-cum random sampling. Out of 600 employees, after the screening through anasakti scale, extreme 60 high as well as extreme60 low respondents were selected in the high and low anasakti groups. Total sample of high and low anasakti groups was further divided into three sub groups ( $\mathrm{N}=20$ in each group) i.e. low level of job, medium level of job and high level of job. 


\section{Tools:}

In the present study following tools were used for the measurement of variables under the study:

\section{Anasakti Scale for Professionals:}

A self-developed of anasakti has been used to measure the ansakti of employees working at various levels of post in different automobile industry. This questionnaire originally developed by Dr. Sanjay kumar (CCS University) containing 47 items related to the nature and behavioral orientation to anasakti. After item analysis a total 40 items were remained in the final draft. The construct validity of the scale was found 0.84 and test- retest reliability of the scale was 0.91 .

\section{Job Satisfaction:}

Job Satisfaction scale (Hindi version) originally constructed by Anukool Hyde, SanjyotPethe and UpindarDhar and published by Vedant publication, Lucknow has been used to measure the job Satisfaction of employees. This scale included 34 items. The split half reliability coefficient was found to be 0.88 and the face validity of the scale was 0.93 .

\section{RESULT:}

Findings of the present study were presented in Table-1

Table-1: Analysis of Variance of Anasakti and Level of Post.

\begin{tabular}{|l|l|l|l|l|}
\hline Sources of Variances & Ss & Df & MS & F \\
\hline Anasakti (A) & 11960.04 & 1 & 11960.04 & $63.33 * *$ \\
\hline Level of Post (B) & 1220.47 & 2 & 640.53 & $3.39 *$ \\
\hline Interaction (A X B) & 2081.06 & 2 & 1040.53 & $5.51 * *$ \\
\hline Error & 21528.90 & 114 & 188.85 & \\
\hline Total & & & & \\
\hline
\end{tabular}

**Significant at 0.01 level of significance.

*Significant at 0.05 level of significance.

A look at the table showing F-ratio of the group of anasakti, i.e, high and low ansakti was found to be $[\mathrm{F}-120(1,114), 63.3, \mathrm{P}<0.01]$ which was found significant at 0.01 level of significance, it means that anasakti an effective variable in influencing job satisfaction of employees; and the Fratio of the variable of level of post was found to be [F-120 $(2,114), 3.09, \mathrm{P}<0.05]$ indicate that level of post was an effective variable in influencing job satisfaction. Finally the F- ratio of 
interaction of anasakti and level of post was found to be [F-120 $(2,114), 5.51, \mathrm{P}<0.01]$ which indicated that the interaction between anasakti and level of post was found to be effect on job satisfaction at .01 level of significance.

\section{DISCUSSION:}

(Tripathi, Naidu, Thapa\& Biswas, 1993) observed that the employees who are low on Asakti (attachment) most often covary with type A personality, scores indicate greater depression, fear, guilt and reported daily hazels comparative to employees high on Anasakti (Non-attachment). Dr. Ira Rosenman (1993) found in their cross-cultural study that Anasakti was associated with lower depression and anxiety, it did not buffer it to a small but significant extent. Thapa (1983) found students high on outcome orientation (Asakti) perceived grater distressed when they encountered stressors and manifested greater syptoms of strain compared to students high on efforts orientation.(Pande\& Naidu, 1986, 1992; Naidu \&Pande, 1990) found Anasakti was a health promoting attitude; employees high on Anasakti are less to govern by external standards such as social approval or censor. His behavior will guided by correctness of conduct and excellence in performance that they are more satisfied as compared to group. Swami chimmayananda (1975) high anasakt employees show total absorption in the task at hand. He would manifest complete involvement in all kinds of tasks that they may undertake dissolving the past fears and futures expectations.(pande\& Naidu, 1990) revels that high Anasakti employees show high concentration on is job work, able to focus on tasks at hand and would not be easily distractible, comfortable on any task with selective ease regardless of what be its affective value for him. This reveals that subjects high on Anasakti have opportunity to develop good personality skill which help them to feel more efficient, social and individually contented

for all the responsibilities at work, whereas low on Non-attachment always busy in managing their personal grievances and never feel satisfied so significant difference was observed in results.

\section{REFERENCES:}

1. Banth, Sudha; Talwar, Charo (2006). Anasakti, the Hindu ideal and its relationship to well-being and orientation to happiness. Journal of religion and health, DOI: 10.1007/s10943-9402-3.

2. Bhushan, L.I. (1994). A yogic Model of mental health. Indian journal of psychological issues, 2, pp: 1-4.

3. Gurin, G., Veroff, J. and Feld, S. (1960). Americans view their mental health. New York: Basic Books.

4. Hagedorn, L.S. (2000). Conceptualizing faculty job satisfaction: Components, theories, and outcomes. In Hagedorn, L.S. (Ed.), what contributes to job satisfaction among faculty and staff? San Francisco: Jossey-Bass.

5. Hanson, R. (2009). Buddha's brain: The natural neuroscience of happiness, love \& wisdom. Oakland, CA: New Harbinger.

6. Herzberg, F. (1959). The motivation to work (2nd ed.), New York: John Wiley \& Sons. 
7. Herzberg, F., Mausner, B., and Snyderman, B.B. (1959). The motivation to work. New York: John Wiley \& Sons.

8. Kohn, M. and Schooler, C. (February, 1973). Occupational experience and psychological functioning: An assessment of reciprocal effects. American Sociological Review, 38, 97 118.

9. Locke, E.A. (1976). The nature and causes of job satisfaction. In Marvin D. Dunnette (Ed.), Handbook of industrial and organizational psychology (p. 1297-1349). Chicago: Rand McNally College Publishing Company.

10. Maslow, A.M. (1970). Motivation and personality. New York: Harper and Row.

11. McGinnis, A.L. (1985). Bringing out the best in people: How to enjoy helping others excel. Minneapolis, MN: Augsburg.

12. Mortimer, J.T. (1979). Highlights of the literature: Changing attitudes toward work. Scarsdale, NY: Work in America Institute, Inc.

13. Newman, J.E. (Dec., 1975). Understanding the organizational structure-job attitude relationship through perceptions of the work environment. Organizational Behavior and Human Performance, 14, 371-397.

14. Padde, P. (1993). An evaluation of the supervisory techniques of the Extension supervisors as they relate to the job performance among the Extension agents in the agricultural Extension service in the eastern region of Uganda. Unpublished masters' theses. Columbus, $\mathrm{OH}$ : The Ohio State University.

15. Pande, N., \& Naidu, R. K. (1992). Anāsakti and health: A study of nonattachment. Psychology and Developing Societies, 4, 89-104. doi:10.1177/097133369200400106

16. Saraswati, Swami Satyananda and Swami Satyasangananda (1984). Karma Sannyasa. Munger: Bihar School of Yoga.

17. Seashore, S.E. and Taber, T.D. (Jan-Feb, 1975). Job satisfaction indicators and their correlates. American Behavioral Scientist, 18, 333-368.

18. Shepard, J.M. (October, 1973). Specialization, autonomy, and job satisfaction. Industrial Relations, 12, 274-281.

19. Tannenbaum, A.S., Kavic, B., Rosner, M, Vianello, M. and Wieser, G. (1974). Hierarchy in organizations. San Francisco: Jossey-Bass.

20. Voydanoff, P. (May, 1978). The relationship between perceived job characteristics and job satisfaction among occupational status groups. Sociology of Work and Occupations, 5, 179-192.

21. Vroom, V.H. (1964). Work and motivation. New York: John Wiley \& Sons. 